farmers cut the figure of state-licensed vandals.) That farming is a social problem is, on the other hand, undeniable: the plight of farmers (and their banks) in the Middle West of the United States during the past two years is one vivid proof. The nub of the difficulty is that most industrialized governments, after decades of encouragement of increased farm production, now find themselves morally committed to a large group of people whose lives have been spent in farming, who have no wish to do anything else and who are not outstandingly fitted to do other things. Governments also recognize, of course, that farmers are also voters, often noisy.

This dilemma is nicely illustrated by the state of British farming. Last year was in many ways disastrous. The government's Annual Review of Agriculture 1986 (HMSO, Cmnd 9708), published at the beginning of the year, showed that as a consequence of the appalling weather, farm income fell in 1985 by 43 per cent compared with the previous year, which had been a good year. In a year when there were 240,000 farms in Britain (a steadily declining number), farmers and their spouses were left with a cash income of merely $£ 1,154$ million, just about half the total scale of subsidy for British farmers last year ( $£ 2,205$ million) and even less than the proportion of the farming subsidy $(£ 1,308$ million) provided by the Common Agricultural Policy by means of which European farming is sustained at an uneconomically high level.

In 1985, in other words, it would have been cheaper for the British taxpayer merely to have provided farmers with the cash they are supposed to have earned from their farming operations and to have bought in their production from the huge stocks of food the Community has built up over the years. Yet farmers are plainly undismayed by this alarming calculation. Farmers spent more on new machinery and building than the cash that stayed in their pockets. while the price of farm land remained buoyant, as the real estate dealers say.

Can this state of affairs be allowed to continue? Common sense says no. Now even the British government seems to be having second thoughts. In the past few weeks, there have been repeated hints that the scale of traditional farming must decline. One common suggestion is that farmers must take to growing other things than the traditional crops, and that British farmers should in particular take to growing trees. The prospect is not checrful. So long as the incentive is financial, the trees that farmers grow will be cheap and nasty (see Nature 322, 101; 1986) like those favoured by the Forestry Commission. Environmental conflicts are more likely to be sharpened than diminished in the process. But trees grow slowly, and will not provide the continuing employment that farmers have come to regard as their birthright, even though the taxation system could no doubt be modified in such a way as to put $£ 1,000$ million plus in their pockets every year. Why not instead bite the unpalatable bullet, and draw up a long-term strategy for the industry that will properly quantify the supposed non-economic benefits, set these off against the equally intangible but important disbenefits of enforced rural life, and declare that the time will have to come. some years from now, when farming will be run on economic lines"?

\section{Shutting barn doors}

\section{The consequences of the Chernobyl accident are about to become diplomatic, thanks to IAEA.}

Wili:N the Soviet reactor at Chernobyl, north of Kiev, went out of control on 26 April, it quickly became apparent, in Sweden where the fallout was first detected and, then, elsewhere in Western Europe, that the formal arrangements for dealing with trans-frontier radioactive pollution are inadequate. At the outset. there wals no obvious means by which the Soviet Union could be required to provide fuller information about the character and the scale of the release of radioactive material from the Chernobyl reactor. (It is now clear that the Soviet officials in charge of the reactor were not themselves aware of what had gone wrong, and that they may even have concealed what they knew about the scale of the accident from Moscow.) Inevitably, the Soviet Union was subjected to a great deal of verbal drubbing from Western governments, many of them eager to complain that Soviet secretiveness, a long-standing nuisance, had become a danger to other people's lives. Yet, curiously, it has been overlooked that, for the past three years, the International Atomic Energy Agency (IAEA) at Vienna has been nursing a kind of international agreement on trans-frontier radioactive pollution. At a conference opening at Vienna later this month, the agency is hoping to turn its draft agreement into an agreement that will stick.

Before this laudable exercise is written off as an attempt to shut the stable (or barn) door after the horse has bolted, some consideration should be given to the complexity of the issues that will arise during the coming weeks. The starting-point for IAEA's conference is the set of recommendations produced in April 1984 on the management of nuclear accidents that might cause fallout beyond the boundaries of the states housing faulty reactors and other nuclear facilities. Sensibly, indeed inevitably, the experts concluded that there should be an element of planning in advance.

Each reactor operator should have a well-defined set of criteria for telling when an accident must be taken seriously, must tell the authorities in neighbouring states about these criteria and must then identify, also in advance, the nuclear installations that are potentially a source of international trouble. All that makes sense, as does the requirement that there should be identified communications links by which news of accidents may be signalled if and when they happen. What IAEA now seeks, in the chastened atmosphere after Chernobyl, is an agreement between its member states that these modest guidelines will be adopted. Whether it will succeed is another matter.

Here are some of the impediments to agreement at Vienna. In many places, the exact design of nuclear installations and even their intended function is still a secret, for either military or quasi-military reasons. The Soviet Union, which declares the nature of its operating reactors to IAEA as a matter of course, says little about its other facilities such as separation plants. France is similarly coy about the division between the civil and military aspects of its nuclear plants.

Other states such as India and Israel (both members of IAEA but non-signatories of the Non-Proliferation Treaty) think they have an interest in keeping their neighbours guessing about their nuclear programmes, believing that their own security will be enhanced if they can give the impression of being capable of making nuclear weapons. Such states will not readily fall in with the suggestion that they should disclose the nature of their nuclear installations.

But even elsewhere, where a state has nothing (or nothing much) to hide, there will be a profound reluctance to say in advance that this or that nuclear plant is in principle capable of going wrong, and of causing trouble to others. Indeed, it is easy to imagine how information of that kind could be used malevolently by those who believe that Chernobyl gives them a licence to halt the nuclear industry in its tracks.

So this month's meeting at Vienna is bound to be a tense affair. Even enlightened governments will be uneasy about the disclosures they will be asked to make. Yet their long-term interest is precisely the kind of undertstanding on the management of major nuclear accidents that IAEA's guidelines would set in place. If one consequence will be the abatement of senseless secrecy in the management of nuclear installations, that will be an uncovenanted benefit of what is, in any case, an essential measure. And the fear that too much openness will put too much ammunition in the hands of the anti-nuclear people is unreal; part of the trouble now is that too many authorities have been too secretive for too long. 